\title{
PEMANFAATAN KAWASAN HUTAN DENGAN TUJUAN KHUSUS (KHDTK) SENARU SEBAGAI SARANA WISATA EDUKASI MELALUI PENGENALAN JENIS VEGETASI
}

\author{
Irwan Mahakam Lesmono Aji, Dwi Sukma Rini, Kornelia Webliana \\ Universitas Mataram, Mataram, Indonesia \\ irwanmla@unram.ac.id
}

\begin{abstract}
Abstrak: Kawasan Hutan Pendidikan Senaru atau disebut juga dengan Kawasan Hutan dengan Tujuan Khusus (KHDTK) Senaru memiliki potensi multi fungsi yang dapat memberikan manfaat ekonomi, lingkungan, pendidikan dan sosial bagi umat manusia. Manfaat tersebut diantaranya berasal dari Hasil Hutan Kayu (HHK) dan Hasil Hutan Bukan Kayu. Selain manfaat yang bersumber dari HHK dan HHBK terdapat juga manfaat jasa lingkungan seperti wisata alam dan pendidikan. Dalam perjalanannya KHDTK Senaru dimanfaatkan sebagai tempat wisata bagi masyarakat baik lokal, nasional maupun internasional yang datang ke KHDTK Senaru untuk menikmati pemandang alamnya atau melewati KHDTK untuk melanjutkan perjalanan mereka menuju puncak Gunung Rinjani. Kondisi ini tentunya merupakan perkembangan yang positif bagi KHDTK Senaru dan pengelola, dalam melakukan pengembangan wisata kedepannya. Permasalahan yang terjadi pada saat ini yaitu belum maskimalnya informasi terkait sumberdaya hutan yang ada pada KHDTK Senaru untuk menunjang wisata edukasi bagi pengunjung maupun masyarakat sekitar terkait dengan alam sekitar, terutama pengenalan jenis vegetasi yang terdapat disepanjang jalur wisata. Sehingga tujuan dilaksanakannya kegiatan pengabdian ini adalah: (1) untuk menyediakan informasi vegetasi yang terdapat pada jalur wisata, (2). menyediakan herbarium vegetasi yang ada sepanjang jalur dan (3) menyediakan papan informasi terkait vegetasi pada jalur wisata. Motode yang digunakan adalah observasi, focus group discussion (FGD), dan sosialisasi. Adapun hasil yang diperoleh adalah sebagai berikut: (1) masyarakat memiliki data terkait jenis-jenis vegetasi yang terdapat pada jalur-jalur wisata, (2) tersedianya herbarium jenis-jenis vegetasi yang ada di sepanjang jalur (3) tersedianya papan informasi terkait jenis-jenis vegetasi yang ada di sepanjang jalur.
\end{abstract}

Kata Kunci: KHDTK; Senaru; wisata edukasi; pengenalan jenis vegetasi

\begin{abstract}
Senaru Educational Forest or also known as Forest Area with Special Purposes (KHDTK) has a multi-functional potency that can provide economic, environmental, educational, and social benefits for people. The benefits are derived from Timber Forest Products (HHK) and Non-Timber Forest Products (HHBK). In addition, there are also benefits from environmental services such as natural tourism and education. KHDTK Senaru is used as a tourist destination ranging from local, national and international tourists who came to enjoy its natural views or pass through to the summit of Mount Rinjani. This condition is certainly a positive development for KHDTK Senaru and the management, in carrying out tourism development in the future. The current problem is the lack of information regarding the forest resources available at the KHDTK Senaru to support educational tourism and the local communities regarding the natural environment, especially the introduction of vegetation species along the tracks. Thus, the aims of this community service program are (1) to provide information on vegetation available along the tourist track, (2) to provide herbariums for vegetation along the tourist track, and (3) to provide information boards related to vegetation available on the tourist track. The methods used are observation, focus group discussion (FGD), and socialization. The results obtained after the program are as follows: (1) the local communities have database regarding list of vegetation species available along the tourist tracks, (2) the availability of herbariums of vegetation on the tourist track, and (3) the availability of information boards of vegetation at the tourist track.
\end{abstract}

Keywords: KHDTK; Senaru; educational tourisme; species identification 


\section{Pendahuluan}

Kawasan Hutan Pendidikan Senaru atau disebut juga KHDTK (Kawasan Hutan dengan Tujuan Khusus) Senaru terletak di Desa Senaru Kecamatan Bayan, Kabupaten Lombok Utara Provinsi NTB $(-8,3058676,116,4010504)$ adalah kawasan Hutan Pendidikan dengan luas areal $\pm 225,7$ ha yang ditetapkan sebagai Kawasan Hutan dengan Tujuan Khusus (KHDTK) berdasarkan Surat Keputusan Menteri Kehutanan Nomor SK.392/Menhut-II/2004. Hutan Pendidikan Senaru saat ini dimanfaatkan sebagai laboratorium lapangan oleh Program Studi Kehutanan Universitas Mataram, sebagai lokasi kegiatan pendidikan, penelitian dan pengabdian kepada masyarakat.

Kawasan hutan Senaru memiliki potensi multi fungsi yang dapat memberikan manfaat ekonomi, lingkungan, pendidikan dan sosial bagi umat manusia. Manfaat tersebut diantaranya berasal dari Hasil Hutan Kayu (HHK) dan Hasil Hutan Bukan Kayu. Hal ini karena hutan Senaru memiliki kekayaan yang cukup beragam. Hal ini sebagaimana disebutkan oleh Kurniawan et al (2012) bahwa Kawasan TNGR sangat kaya akan keanekaragaman hayati flora dan fauna sebagai sumber plasma nutfah, Potensi ini dapat dijadikan untuk pengembangan ilmu pengetahuan, pendidikan, penelitian dan wisata alam (Prastiyo et al, 2016). Lebih lanjut, penelitian mengenai jenis vegetasi khususnya di KHDTK Senaru telah dilakukan dengan hasil survei terdapat total 32 jenis vegetasi yang tersusun dalam tingkat semai, pancang, tiang dan pohon. Beberapa vegetasi penyusun merupakan penghasil produk hasil hutan bukan kayu, yaitu Gaharu (Gyrinops verstegii), Kemiri (Aleurites moluccana), Durian (Durio zibenthinus), dan Nangka (Artocarpus heterophyllus) (Idris, et al, 2013). Lebih lanjut hasil penelitian Aji et al (2014), menunjukkan bahwa di KHDTK Senaru ditemukan jumlah spesies tumbuhan berguna sebanyak 36 jenis, dimana 6 jenis diantaranya termasuk spesies dilindungi.

Selain manfaat yang bersumber dari HHK dan HHBK terdapat juga manfaat jasa lingkungan seperti wisata alam dan pendidikan. KHDTK Senaru dimanfaatkan sebagai tempat wisata bagi masyarakat baik lokal, nasional maupun internasional yang datang ke KHDTK Senaru untuk menikmati pemandang alamnya atau melewati KHDTK untuk melanjutkan perjalanan mereka menuju puncak Gunung Rinjani. Hal ini karena, Senaru merupakan salah satu pintu masuk menuju puncak Rinjani selain dari Sembalun. Hal ini menjadi semakin berkembang setelah pada tahun 2016, pada kawasan ini dibangun lokasi viewpoint untuk menikmati pemandangan air terjun dari atas dan juga dibuka warung-warung makanan dan minuman yang dipublikasi melalui media sosial maupun lainnya menyebabkan banyak pengunjung yang berdatangan. Sektor pariwisata telah tumbuh menjadi sektor unggulan di NTB, khususnya di Lombok. Yahya (2015) mengemukakan bahwa sector pariwisata telah tumbuh menjadi sektor yang unggul dan memiliki pertumbuhan yang cepat dan dapat memberikan kontribusi pada pertumbuhan ekonomi sebesar 9,5\% pada PDB (produk Domestik Bruto) global.

Tujuan dilaksanakannya kegiatan pengabdian dalam bentuk pengenalan vegetasi ini adalah: (1) untuk menyediakan informasi (database) vegetasi pada jalur wisata, (2). menyediakan herbarium vegetasi yang ada sepanjang jalur dan (3) menyediakan papan 
informasi terkait vegetasi pada jalur wisata.

Sementara manfaat yang akan diperoleh dari hasil pengenalan vegetasi ini adalah: (1). informasi vegetasi pada jalur wisata yang lengkap yang dapat dijadikan dasar bagi pengelola untuk mengelola KHDTK Senaru, (2). herbarium sebagai koleksi pengelola KHDTK Senaru, (3). memberikan edukasi, baik kepada petani lokal maupun pengunjung, terkait vegetasi yang ada pada wilayah KHDTK Senaru.

Semenjak 2004 hingga saat ini, pengelolaan kawasan KHDTK Senaru terkesan stagnan, dimana berdasarkan beberapa hasil penelitian menunjukkan belum adanya perubahan yang nyata pada kesejahteraan masyarakat yang terlibat dalam pengelolaannya. Selama ini masyarakat hanya memanfaatkan HHK dan HHBK sebagai sumber pemasukannya. Senaru merupakan salah satu pintu masuk menuju puncak Rinjani selain dari Sembalun. Semenjak tahun 2016, pengelolaan KHDTK Senaru semakin berkembang, pada kawasan ini dibangun lokasi viewpoint untuk menikmati pemandangan air terjun Tiu Kelep dari atas dan juga dibuka warung-warung makanan dan minuman yang dipublikasi melalui media sosial maupun lainnya menyebabkan banyak pengunjung yang berdatangan. Untuk mendukung hal tersebut, masih banyak dibutuhkan informasi-informasi yang dipampang agar pengunjung dapat mendapatkan informasi yang baik tentang kondisi KHDTK Senaru terutama vegetasi didalamnya.

\section{Metode}

Kegiatan Pengenalan vegetasi bersama masyarakat di Kawasan Hutan dengan Tujuan Khusus (KHDTK) Senaru dilaksanakan pada bulan Juli-September 2017, berlokasi di Desa Senaru Kabupaten Lombok Utara Provinsi Nusa Tenggara Barat.

Metode yang digunakan dalam kegiatan ini dilaksanakan dengan 2 tahap yaitu sosialisasi dan observasi langsung. Tahapan Sosialisasi dilakukan dengan tujuan untuk memberikan gambaran umum terkait informasi vegetasi dan nilai penting vegetasi pada jalur wisata Senaru. Kegiatan sosialisasi ini dikemas dengan kegiatan FGD (focus Group discussion), yang merupakan kegiatan pengumpulan data kualitatif dimana sekelompok orang berdiskusi tentang suatu fokus masalah atau topik tertentu dipandu oleh seorang fasilitator (Indrizal, 2014). Kelompok yang dimaksudkan pada kegiatan ini adalah petani pengelola lahan KHDTK Senaru.

Observasi langsung adalah pengamatan secara langsung pada subjek yang ada dilapangan seperti prilaku, pertumbuhan, dan sebagainya, pada waktu kejadian itu berlangsung atau pada waktu prilaku tersebut terjadi (Nazir, 2014). Observasi dapat dibedakan menjadi non sistematis dan sitematis. Pada kegiatan pengabdian ini observasi langsung dilakukan pada proses identifikasi vegetasi pada jalur wisata menggunakan panduan lapangan identifikasi pohon. Jenis observasi ini dikategorikan sebagai observasi sistematis. Menurut Arikunto (2014) observasi sistematis yaitu pengamat menggunakan pedoman pada saat instrument pengamatan berlangsung.

Metode yang juga menjadi perhatian dalam kegiatan ini adalah pembuatan herbarium sebagai koleksi dan sarana pembelajaran bagi masyarakt local dan pengunjung. Herbarium adalah kumpulan spesimen tanaman kering yang diawetkan dengan hati-hati, diberi label, dan 
diatur untuk referensi. Herbarium adalah sumber daya yang sangat berharga untuk mempelajari botani, taksonomi dan hortikultura. Spesimen herbarium memberikan catatan sejarah tentang: apakah tumbuhan itu tumbuh di tempat tertentu, dan kapan. Mereka memberikan wawasan tentang sejarah, evolusi, pemuliaan tanaman, distribusi, taksonomi, variasi dan hubungan spesies tanaman. Dalam membuat herbarium, mengacu kepada Iwanycki (2009).

Adapun tahapan-tahapan kegiatan pengabdian yang dilakukan adalah sebagai berikut:

1. Tahapan survei vegetasi berkayu pada jalur wisata (tertentu) meliputi Identifikasi vegetasi dan mengambil titik-titik koordinat lokasi vegetasi dengan bantuan GPS.

2. Tahap pemilihan jenis.

3. Tahap pengambilan sampel vegetasi sebagai bahan pembuatan herbarium.

4. Tahap pembuatan papan.

5. Tahap sosialisasi kepada masyarakat terkait jenis. Pada tahapan sosialisasi, dilakukan pemaparan materi oleh tim kepada masyarakat (petani pengelola lahan KHDTK Senaru) berkaitan dengan arti penting pengenalan vegetasi KHDTK Senaru. Pada kesempatan ini, dilakukan diskusi dimana masyarakat diberikan kesempatan baik bertanya, menyampaikan pendapat dan aspirasinya. Terakhir, dilakukan perumusan hasil diskusi untuk ditindaklanjuti.

6. Tahap pemasangan papan bersama masyarakat.

\section{Hasil dan Pembahasan}

Kegiatan yang dilakukan pada KHDTK Senaru secara umum bertujuan untuk mengembangkan wisata edukasi berbasis pengenalan komponen vegatasi penyususn KHDTK. Hasil berdasarkan tahapan-tahapan yang telah disampaikan pada bagian metode, diperoleh data jenis-jenis vegetasi pada dua jalur sebagaimana dipaparkan dalam Tabel 1. Selanjutnya hasil vegetasi yang telah disurvei dan diambil titik koordinatnya diolah menjadi peta jalur persebaran vegetasi yang dapat dilihat pada gambar 1 dan gambar 2 .

Kegiatan sosialisasi dilakukan kepada masyarakat yang bermata pencaharian sebagai petani penggarap, sebagai naturalis guide, porter dan lain lain. Untuk menunjang pencapaian tujuan penyuluhan yang efektif dan efesien, maka penyampaian materi penyuluhan dipilih metode Fokus Group Discussion (FGD), sehingga masyarakat kesempatan menyampaikan pendapat dan aspirasinya dengan diskusi/tanya jawab. Adapun isi materi penyuluhan terdiri dari tiga pokok bahasan yaitu sebagai berikut :

1. Pengenalan jenis vegetasi dan manfaat pemberian informasi terkait penyebaran vegetasi di kawasan KHDTK Senaru.

2. Pengembangan wisata Edukasi di kawasan KHDTK Senaru

3. Teknik pembuatan Herbarium 
Tabel 1. Jenis Vegetasi Hasil Survei pada Jalur Lutung dan Jalur Celepuk

\begin{tabular}{|c|c|c|c|c|c|c|c|}
\hline \multirow{2}{*}{ No } & \multicolumn{3}{|c|}{ Jalur Wisata Pengamatan Lutung } & \multirow{2}{*}{ No } & \multicolumn{3}{|c|}{ Jalur Wisata Pengamatan Celepuk } \\
\hline & Nama Lokal & Nama Ilmiah & Jumlah & & Nama Lokal & Nama Ilmiah & Jumlah \\
\hline 1 & Bajur & Pterospermum javanicum Jungh & 3 & 1 & Bajur & Pterospermum javanicum Jungh & 2 \\
\hline 2 & Brune & Antidesma bunius & 1 & 2 & Borok/Dadap & Erythrina subumbrans & 9 \\
\hline 3 & Borok/Dadap & Erythrina subumbrans & 9 & 3 & Kemiri & Aleurites moluccana & 8 \\
\hline 4 & Ela ela & Alphonsea sp & 1 & 4 & Klanjuh/Weru & Albizia procera & 2 \\
\hline 5 & Kemiri & Aleurites moluccana & 2 & 5 & Mahoni & Swietenia macrophylla King & 38 \\
\hline 6 & Lemboke & Ficus septica Burm. F. & 1 & 6 & Embur & Trevesia lateriflora & 1 \\
\hline 7 & Lempinyo & Aglaia edulis & 1 & 7 & Mendong & Trema orientalis $\mathrm{BI}$ & 1 \\
\hline 8 & Litak/Pulai & Alstonia scholaris & 1 & 8 & Rajumas & Duabanga moluccana $\mathrm{Bl}$ & 1 \\
\hline 9 & Lungsir & Syzygium littorale & 4 & 9 & Randu & Ceiba pentandra & 4 \\
\hline 10 & Melak Daun & Rourea mimosoides & 4 & 10 & Salinguru & Actinodaphne diversifolia Merr & 2 \\
\hline 11 & Mendong & Trema orientalis $\mathrm{BI}$ & 1 & 11 & Sengon & Paraserianthes falcataria L. Nielsen & 35 \\
\hline 12 & Sebia daya & Malestoma malabthricum & 1 & 12 & Sengon Buto & Enterolobium cyclocarpum (Jacq.) Griseb & 1 \\
\hline 13 & Sengon & Paraserianthes falcataria L. Nielsen & 1 & 13 & Suren & Toona sureni & 4 \\
\hline 14 & Seropan & Macaranga tanarius (L.) Muell. Arg & 9 & 14 & & & \\
\hline 15 & Sonokeling & Dalbergia latifolia & 1 & & & & \\
\hline 16 & Suren & Toona sureni & 3 & & & & \\
\hline 17 & Pandawa & Astronia papetaria & 10 & & & & \\
\hline 18 & Temek & Mallotus dispar & 1 & & & & \\
\hline
\end{tabular}

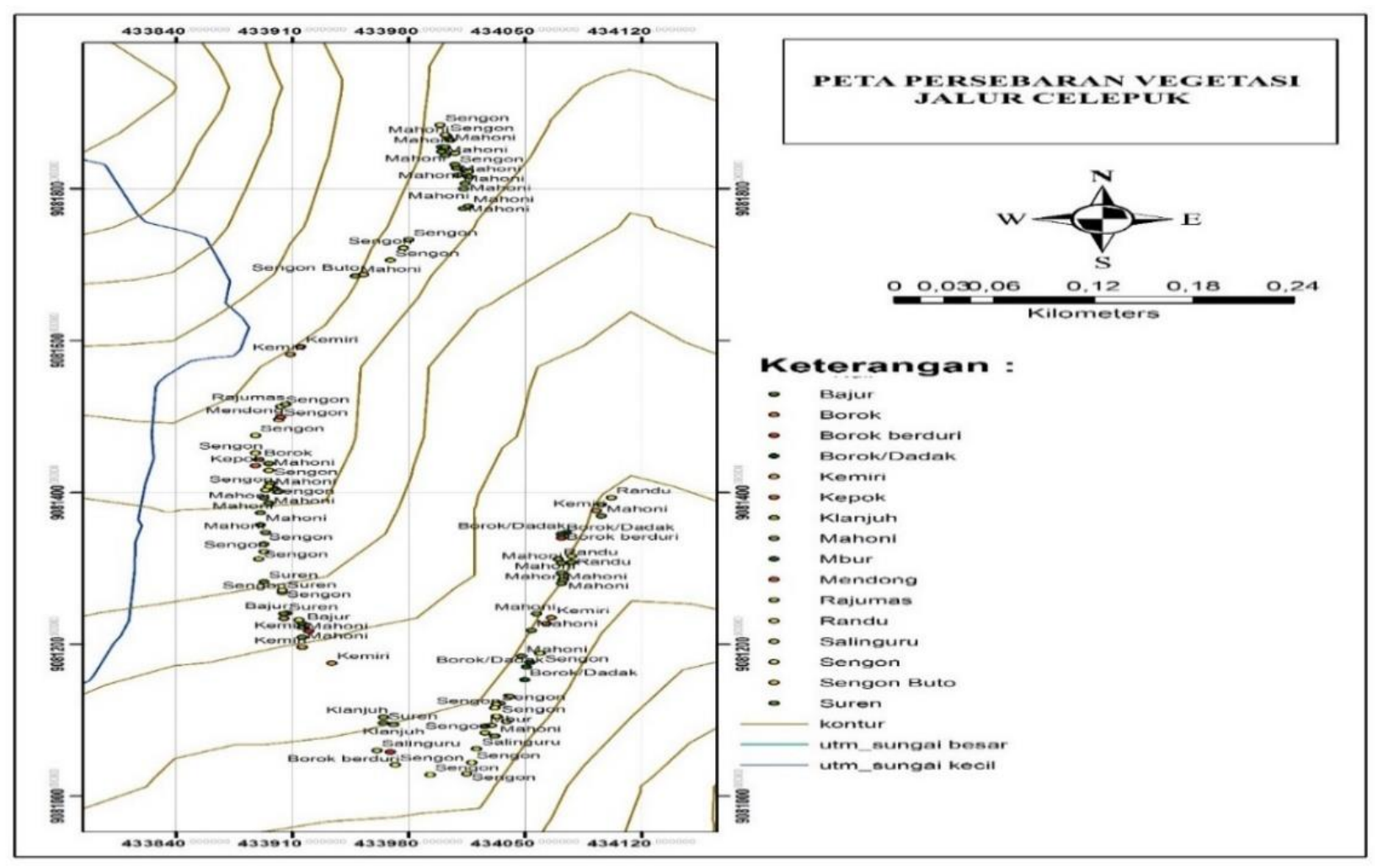

Gambar 1. Peta Persebaran Vegetasi Pada Jalur Celepuk Rinjani 


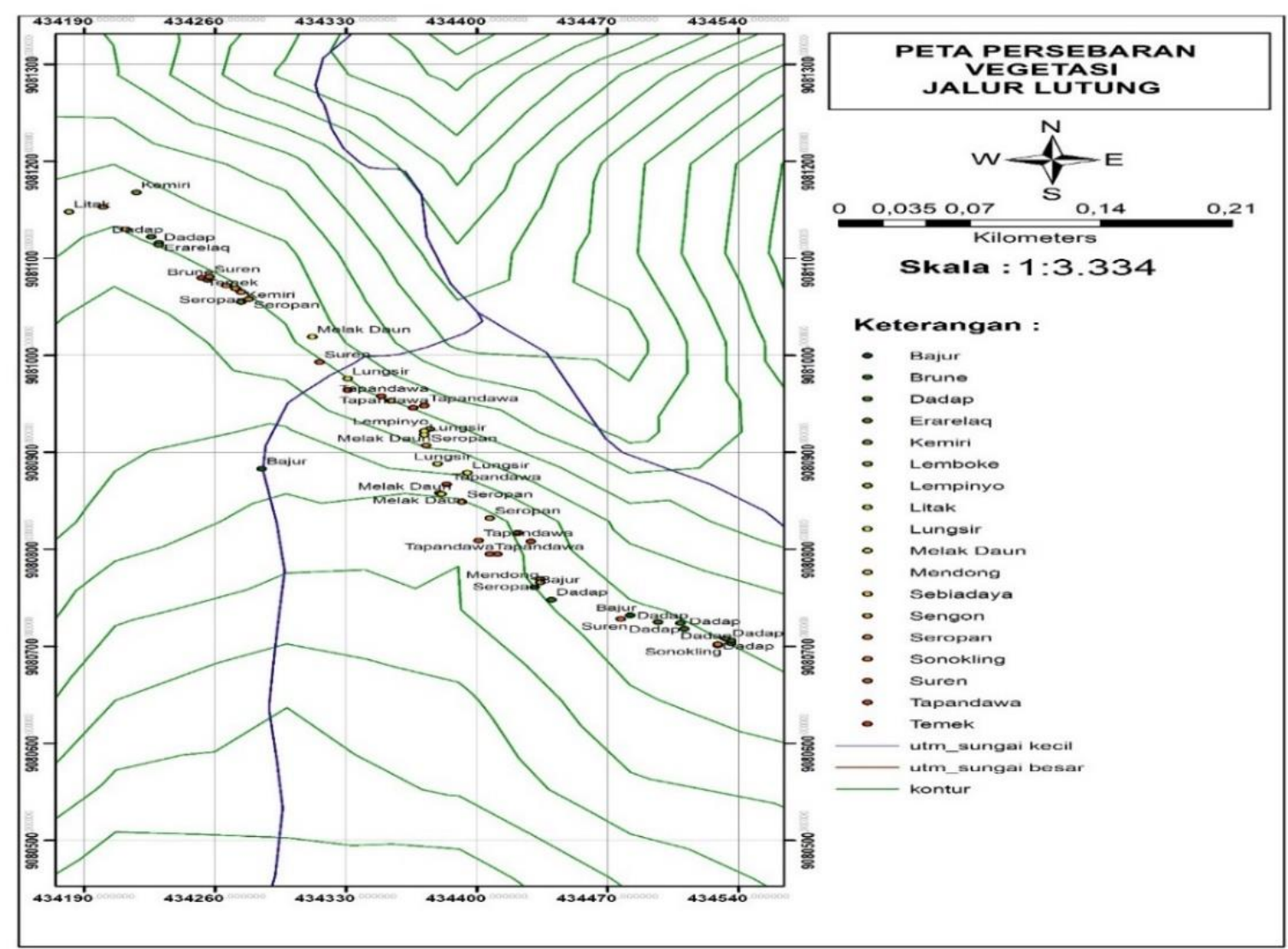

Gambar 2. Persebaran Vegetasi Pada Jalur Lutung

Setelah penyampaian materi disampaikan, dilakukan sesi diskusi/tanya jawab dengan peserta penyuluhan. Dalam sesi ini penyuluh mencatat informasi dan pertanyaan yang dikemukan oleh masyarakat dan memberikan tanggapan serta solusi dari persoalan yang disampaikan. Pertanyaan pada saat sesi diskusi adalah seputar: (1) cara mempromosikan wisata edukasi kepada wisatawan; (2) penurunan jumlah komponen vegetasi penyusun di dalam kawasasn KHDTK senaru dapat mempengaruhi satwa liar yang ada di dalam kawasan; (c) pengaruh komponen vegetasi pada kawasan KHDTK senaru, bagaimana cara mengatasinya; (d) alasan pemberian identitas vegetasi hanya pada jalur Lutung dan jalur Celepuk rinjani; (e) cara membuat paketan wisat minat khusus dan wisata edukasi untuk KHDTK Senaru. Berikut ini merupakan gambaran jalannya kegiatan sosialisasi dengan masyarakat.

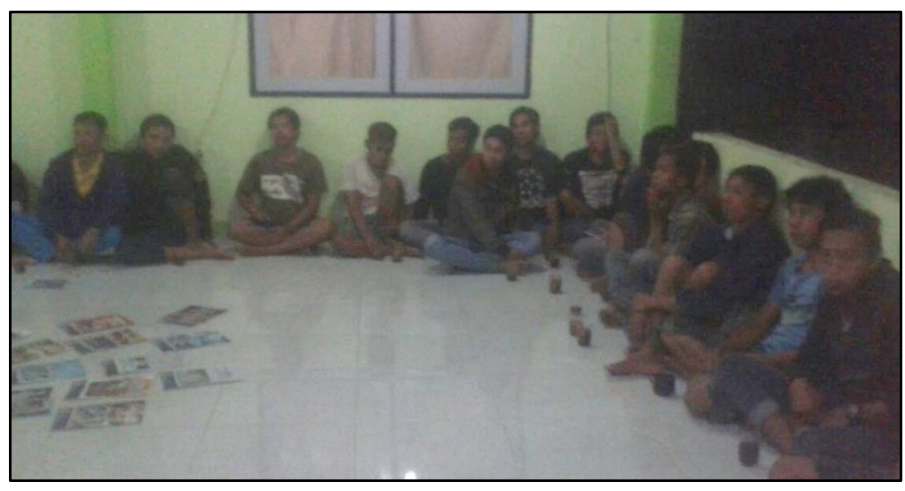

Gambar 3. Kegiatan Pengabdian di Dalam Ruangan 
Tahapan selanjutnya adalah pemasangan papan identitas vegetasi pada jalur Lutung (Trachypithecus) dan jalur Clepuk Rinjani (Otus jolanodea). Pemasangan papan informasi dilakukan bersama masyarakat dengan tujuan agar masyarakat mampu mengenali manfaat vegetasi yang ada pada kawasan KHDTK dan mempromosikan wisata edukasi pada wisatawan, gambaran kegiatan pemasangan papan identitas vegetasi dapat dilihat pada gambar berikut:

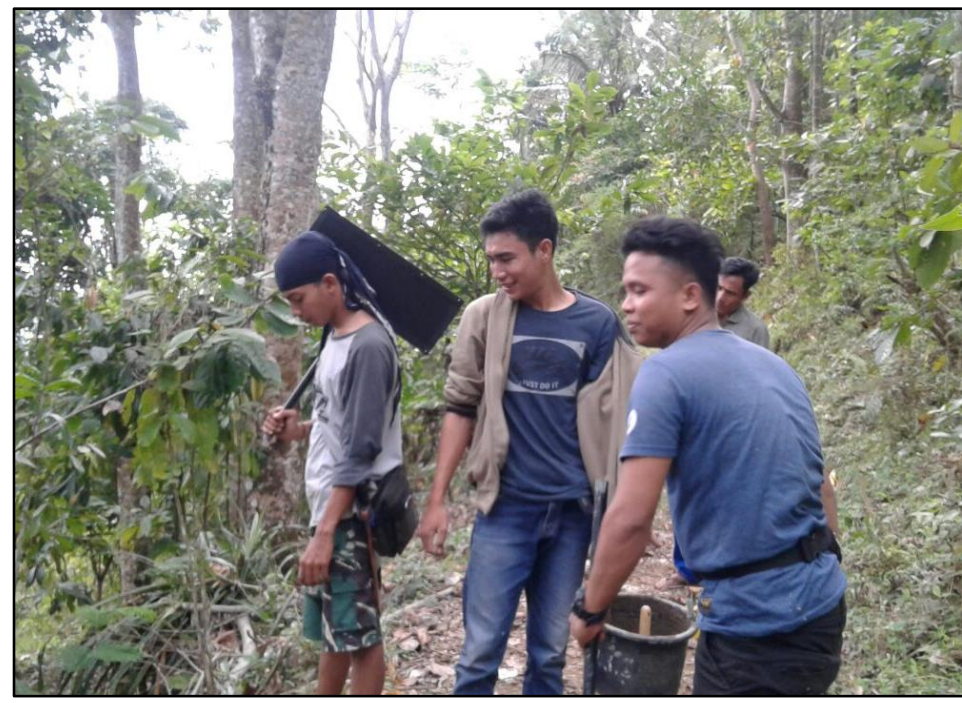

Gambar 4. Persiapan Pemasangan Papan Identitas Bersama Masyarakat

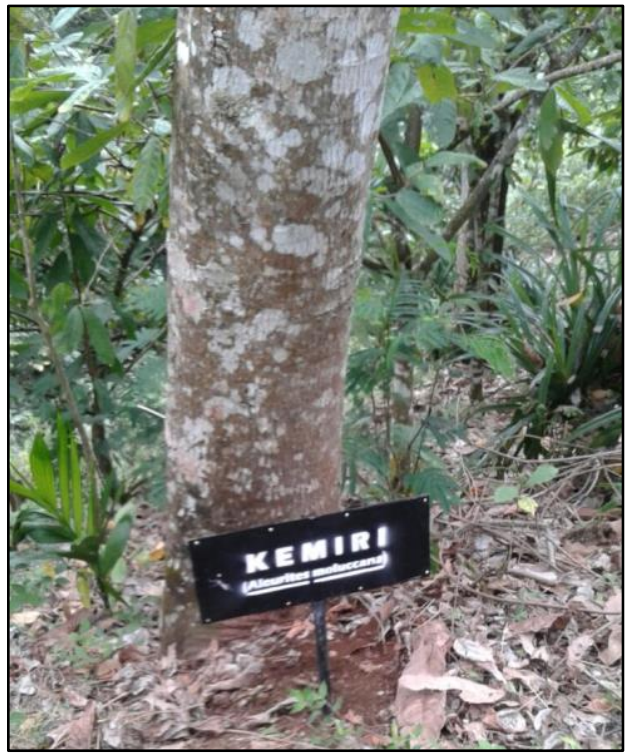

Gambar 5. Hasil Pemasangan Papan Identitas pada Salah Satu Vegetasi di KHDTK Senaru

Dari serangkaian kegiatan penyuluhan yang telah dilaksanakan dapat disimpulkan bahwa penyuluhan ini berjalan dengan baik, hal ini tercermin dari antusias masyarakat memberikan informasi pada saat identifikasi jenis, keikutsertaan dalam kegiatan pengambilan titik koordinat serta pemasangan papan informasi vegetasi. Selain itu kesungguhan dan keseriusan peserta dalam mengikuti dan menanggapi setiap meteri yang diberikan juga menunjukan materi yang diberikan sesuai dengan kebutuhan masyarakat di sekitar kawasan KHDTK Senaru. Namun 
Fenomena yang ditunjukan oleh peserta penyuluh seperti dikemukan diatas, hanya dapat digunakan sebagai petunjuk adanya kemampuan peserta dalam aspek kognitif dan aspek afektif, akan tetapi belum dapat dijadikan tolak ukur untuk mengetahui apakah materi yang dibutuhkan benar-benar telah diterapkan oleh masyarakat peserta penyuluhan, oleh karena itu sangat diperlukan pemantauan lebih lanjut pada waktu yang akan datang.

\section{Kesimpulan}

Dari kegiatan penyuluhan yang telah dilaksanakan terlihat adanya respon yang tinggi dari peserta. Sehingga terdapat beberapa hal yang dapat dirangkum menjadi suatu kesimpulan pelaksanaan kegiatan yaitu masyarakat memiliki data terkait jenis-jenis vegetasi yang terdapat pada jalur-jalur wisata, tersedianya herbarium jenis-jenis vegetasi yang ada di sepanjang jalur, dan tersedianya papan informasi terkait jenis-jenis vegetasi yang ada di sepanjang jalur

\section{Referensi}

Aji, I.M.L., Indriyatno, Wahyuningsih, E., \& Rini, D.S. (2014). Studi Jenis-jenis dan Potensi Pengembangan Hasil Hutan Bukan Kayu (HHBK) di Kawasan Hutan Dengan Tujuan Khusus (KHDTK) Senaru. Laporan Penelitian. Universitas Mataram.

Arikunto, S. (2014). Prosedur penelitian Suatu Pendekatan Praktik. Penerbit Rineka Cipta. Jakarta Idris, M.H., Latifah, S., Aji, I.M.L., Wahyuningsih, E., Indriyatno \& Ningsih, R.V. (2013). Studi Vegetasi Dan Cadangan Karbon Di Kawasan Hutan Dengan Tujuan Khusus (KHDTK) Senaru, Bayan Lombok Utara. Jurnal Ilmu Kehutanan. 71 ). Hal. 25-36.

Indrizal, E. (2014). Diskusi Kelompok Terarah Focus Group Discussion (Prinsip-Prinsip dan langakh pelaksanaan Lapangan). Artikel Ilmiah. Universitas Andalas. Padang

Iwanycki, N. (2009). Guidelines for Collecting Herbarium Specimens of Vascular Plants. Royal Botanical Gardens. Diakses di <https://www.rbg.ca/Document.Doc?id=125>.

Kurniawan, S., Nasriyanto, A.B., Supriyanto, Budi, A.S.E. \& Mertha, I.G. (2012). Buku panduan pengenalan jenis pohon di sepanjang jalur pendakian Taman Nasional Gunung Rinjani. Kementerian Kehutanan, Dirjen PHKA, Balai Taman Nasional Gunung Rinjani.

Nazir,M. (2014). Metode Penelitian Cetakan ke-10. Penerbit Ghalia Indonesia. Bogor

Prastiyo, P., Ismail, M., Basith A., dan Sazali M. (2016). Studi Diskripsi Hubungan Antara Naturalness Index dan Biodiversitas Indexdengan Iklim Mikro pada Kelurahan jatimulio, Mojolangu, dan Mergosonodi Kota Malang. Biota. 9(1). Hal. 18-31

Yahya, A. (2015). Sambutan Menteri Pariwisata R.I. pada Peringatan World Tourism Day dan Hari Kepariwisataan Nasional. Kementerian Pariwisata Republik Indonesia. Diakses pada tanggal 19 Desember 2016. Diakses di <http://www.kemenpar.go.id/post/sambutan-menteripariwisata-ri-pada-peringatan-world-tourism-day-dan-hari-kepariwisataan-nasional $>$. 